\title{
舌癌の原発巣進展範囲と再発・転移樣式に関する研究
}

\author{
東京医科大学耳鼻咽喉科学教室（主任：船坂宗太郎教授） \\ 大 山 和一郎
}

\section{INCIDENCE OF LOCAL RECURRENCE AND REGIONAL LYMPH NODE METASTASIS OF CANCER OF THE TONGUE IN RELATION TO THE LOCATION OF THE TUMOR}

WAICHIRO OHYAMA, M. D.

Department of Otolaryngology, Tokyo Medical College, Tokyo

In 40 cases of the cancer of the tongue, the relationship between the location of the primary tumor and the incidence of local recurrence and cervical lymph node metastasis was examined. Incidence of the local recurrence was high when the safety margin was less than $0.5 \mathrm{~cm}$ at the median site and the tumor invaded to or adjacent to the floor of the mouth and anterior piller. There was no difference in the incidence of local recurrence between mandibulectomized and unmandibulectomized cases. Onset of local recurrence was within 6 months after surgery. Lymph node metastasis was observed at the ipsilateral submaxillary and upper deep cervical lymph nodes. High incidence of cervical lymph node metastasis was found when the cancer extended to the floor of the mouth and the prophylactic neck dissection is recommended in these cases.

Key words: 舌扁平上皮癌, 外科療法, 進展様式, 局所再発, 頸部転移

A87-1483-42334

\section{緒} 言

㙏の臨床病理に関する統計的な検討は, 過去数多く の報告をみる.そして, これらの検討から舌癌の臨床像 として, 男性に多い, 年龄的には 50〜60歳台に多発す る, 舌縁に多い, 組織学的には扁平上皮癌が多い, 所属 リンパ節への転移が多い，潜伏リンパ節転移が多い，等 があげられる(12)334).

治療の面から考えると早期例飞は放射線治療優先, 特

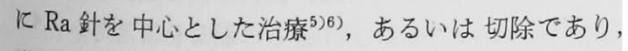
進行例に対しては放射線治療を先行させた外科療法優先 の治療をとるむのが多い78). また, 頸部リンパ節転移

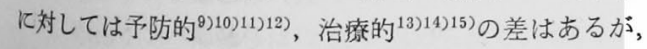
根本的頙部郭清術が一般的である. しかし, 経過中に転 移, 再発の出現する例は当然のことながら予後が悪くな
$ろ^{16) 17)(8) 19)}$.

現在の舌癌治療の主眼は局所再発の阻止にある．また 一旦局所や頸部に再発をきたした場合はそれを早期に発 見, 治療することにより生存率の上昇をはかることが肝 要である. 局所再発を防ぐには, 十分な範囲の切除が必 要であることは言をまたない，しかし切除範囲が大きけ れば大きい程術後の機能障害む強く, それ故術後機能を も考㢜した適切な切除笘囲の決定が重要となる. 特に, 進行例での切除範囲の決定に拈いて, 中咽頭側壁, 前口 蓋弓, 下顎骨等の周囲組繊をどこまで切除すれば良いか は機能を温存する点とあいまって難しい問題が山積して いる.

本研究では, 国立がんセンター䫄頸部で外科療法が施 行された舌癌症例を対象としてその腫瘍の進展様式と局 
所再発、頸部りンバ節县移等との関連について検行を加

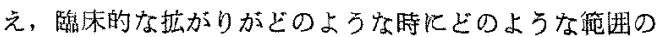
切除方必要か考察を試みた。

\section{研究対象および万法}

過去の坏告では, 舌痁の局所再発, 頸部転移は治療後

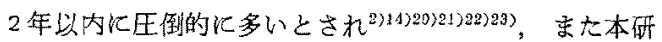
究は雪発の出現部位を主眼ししているため，一次治漛後 現在まで 2 年以上経過している症例を対象とした。

舌癌で再発，层移をきたす症例ときたさない症例につ いて，その切除標本を詳細に㛟索することにより而者の

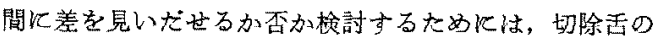

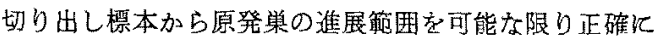

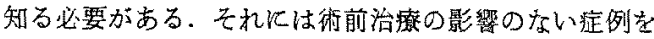

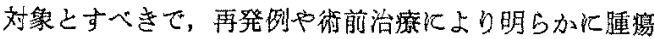
が縮小してしまった症例等の原発策の進展範㽢は種々の 裂素で修䬦されていると考えられるため，今国の研究の 対象加ら除外した。

昭和40年加556年017年間飞国立がんセンター頭頸科 で加療した舌㿑症例 531 例中外科療法を主体行った府 平上皮癌新鮮例で，術前治療を加无ていないむの，ある W山術前の放射線治療が $3000 \mathrm{rad}$ 以下て原発紧の所見

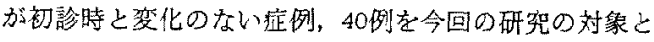
Lた.

原発蚌の淮展様式は，舌切除標本の切り出し時の肉服

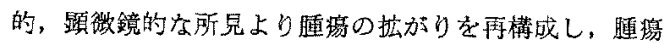
の占罢部位により舌可動部前方限局群，舌可動部後方限

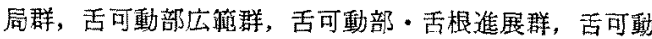

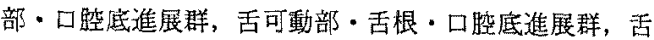
可動部・舌根・目腔底・前口蓋弓進展群の 7 群に分類し た、そしてその各々の再発率とその部位，頸部りンパ節 転移の発生とその部位について検討した（表 1)

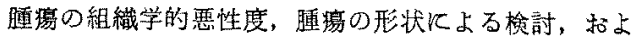

表 1 腄坵占居部位

\begin{tabular}{|c|c|}
\hline 一前方 & 6 例 \\
\hline 舌可動部限局一一後方 & 6 \\
\hline 一広簵 & 4 \\
\hline 舌可動部・舌根 & 6 \\
\hline 舌可動部・口腔底 & 5 \\
\hline 舌可勳部·舌根・口照底 & 8 \\
\hline 舌可動部 ·舌根 · 口腔底・前口蓋弓 & 5 \\
\hline
\end{tabular}

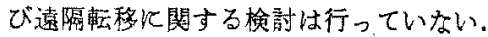

国立がんセンターに和ける舌癌の治療方針は，1962年 開院当初より概ね一貫している。すなわち $\mathrm{T} 1$ 症例炕は $\mathrm{Ra}$ 剑，T2 症例ては舌可動部限局，外问的発育例飞は

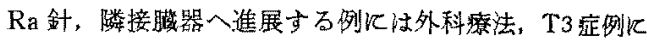
は外科療法主体，しかし舌可動部で外向的発育を示す

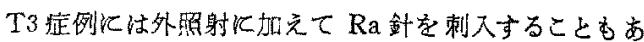

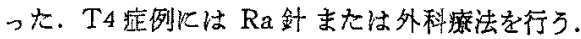

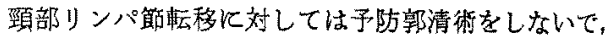
転移が出現すれば根本的頸部郭清術を施行するのを原則 としている210724. 以上の理由から，今回の対象となっ た症例憔展例吕多く，早期例は少ない結果となってい る。

ここで部分切除とはロ部舌の1/2 以下の切除を言い, その多くはロ内法である。半切除とは舌根までの舌半倒 を舌骨上組織もるとも切除するものとした，要全墒出性 舌半切以上て刘側舌根の一部を残したものである。全摘

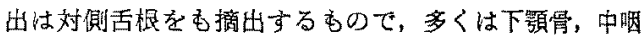
頭を索合併切除している。

\section{研究結果}

\section{a. 症例分布}

対象の性別㹥，男性 31 例，女性 9例だった，年堬住 江男性 $31 \sim 73$ 歳, 平均 52.5 藏, 女性 42 84藏, 平均 62.7 歳, 全体の平均は 54.8 歲だった。

\section{b. TN分布}

U.I.C.C. の臨束病期分類（1978）にもとづく庭例の 分布は表 2 のごとくである。症例は幅広い分布定示して いるが丁1は4例と少ない，こ礼は先にも述へたごと

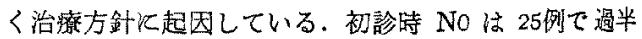
数を占めているが，後発りンパ節転移が 12 例飞認めら れ，現在まで頸部リンパ節耺移のない症例は12例にす ぎない.

表 2 検討庭例 TN 分布

\begin{tabular}{cccccc}
\hline & No & N1 & N2 & N3 & \\
\hline T1 & 4 & & & & 4 \\
T2 & 9 & 2 & 1 & & 12 \\
T3 & 6 & 3 & 2 & 2 & 13 \\
T4 & 6 & 4 & 0 & 1 & 11 \\
\hline & 25 & 9 & 3 & 3 & 40 \\
\hline
\end{tabular}




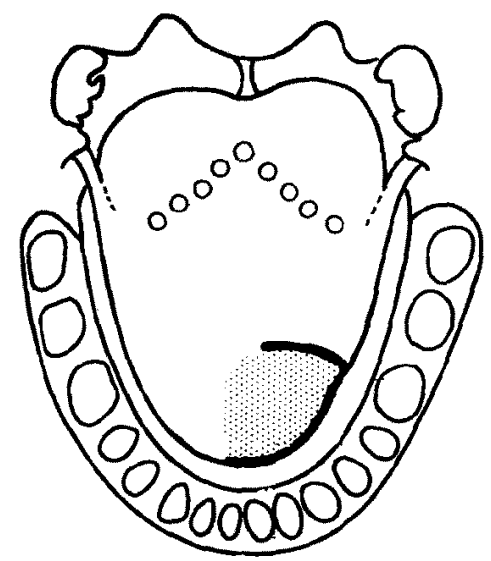

図 1-1 舌可動部前方限局群

丧 3

\begin{tabular}{|c|c|c|c|c|}
\hline 舌 & 下顎骨 & 他 & 列数 & 局所再登 \\
\hline 部分切除 & & & 6 & $\Leftrightarrow$ \\
\hline
\end{tabular}
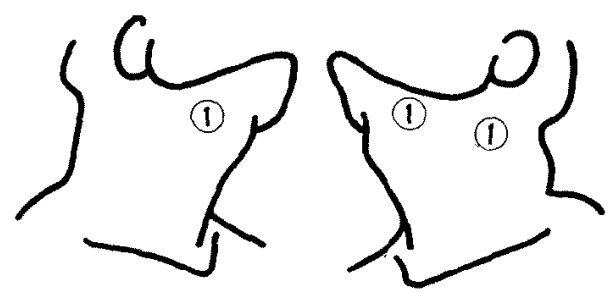

図 1-2 頸部転移 2 例

○の中の数字は，乙の部沉移志認めた症例数 を示す。

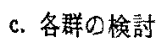

1) 第 1 群: 舌可動部前方限局群（图 1-1）

定例数 6 例

(1) TN 分席

T1：2例，T2：4例で全例 Noだった。

(2) 切除籍国之局所再発（表 3)

全例舌部分切除のみ施行したが，いずれも局所再 発はなく5年生存している.

(3) 頸部リソパ節耺移（因 1-2）

面部リンパ節枟栘は 2 例化認められているが，い すれれを後発耺移だった。

2）第 2 群: 舌可動部後方限呞群 (园 2-1)

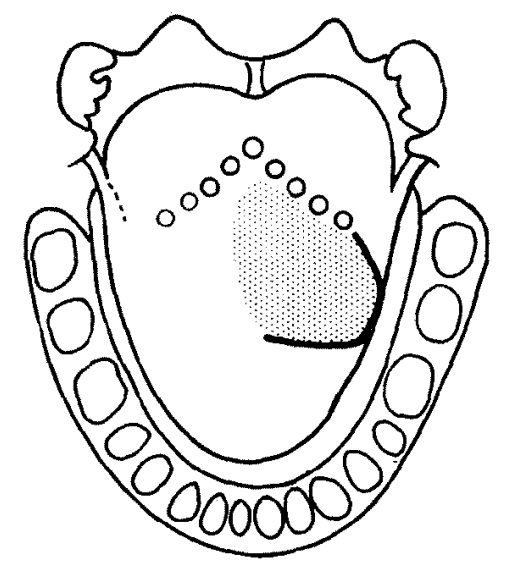

图 2-1 舌可動部後方限鼠群 表 4

\begin{tabular}{|c|c|c|c|c|}
\hline 舌 & 下䪽骨 & 他 & 例数 & 局所再発 \\
\hline 部分切除 & & & 4 & $(-)$ \\
\hline 半切除 & & & 4 & $(-)$ \\
\hline
\end{tabular}

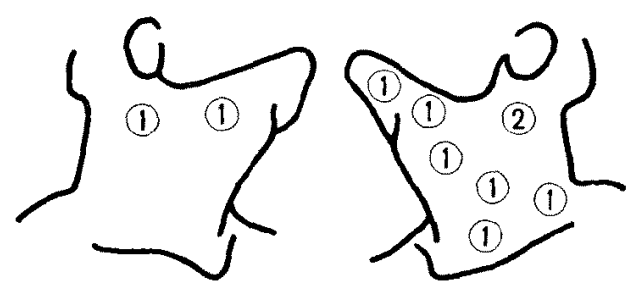

図 2-2 到部転移 3 例

症例数 6例

(1) $\mathrm{TN}$ 分布

$\mathrm{T} 1, T 2, T 3$ 各 2 例でT3 の1例の子 $\mathrm{N}(+)$ て 他山すバ Noだった。

（2）切除籍围已局所尃発 (表 4)

舌部分切除を 4 例に，半切除を2例に施行したが

いずれも局所雨発はない。

(3) 頸部リン八゙節転移 (因 2-2)

莖部リンパ節転移は 3 例に認められたが初晾時よ り転移を䛱め大のは1例のみであり，他2例は後愽 秐移だった。同側，対側之も上深䜖部，顎下部飞子 られたが，後発耺移の1例では術後6力月で同側頸 部儿広筙な枟移をきたした。 


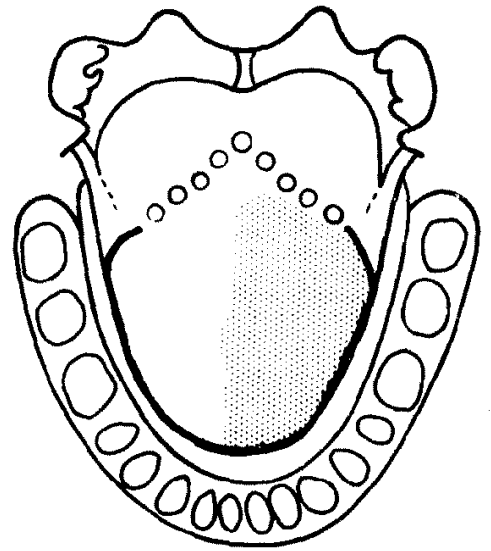

图 3-1 舌可勘部広籍群

表 5

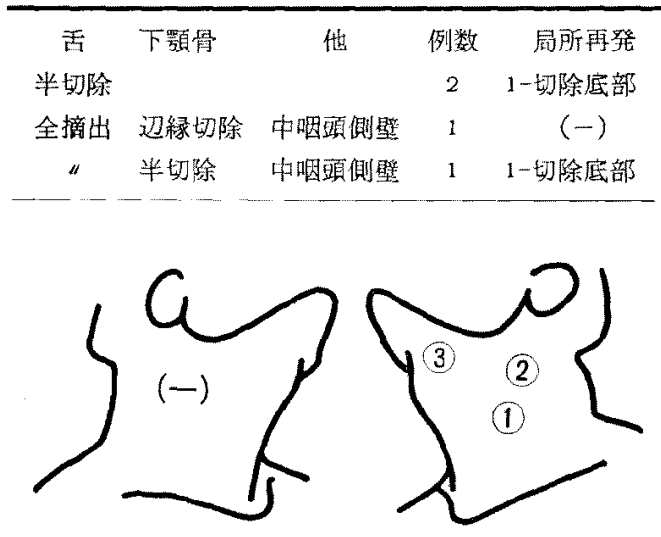

図 3-2 形部転移 3 例

腫晹死は2例で，1例は原発染の制御できた頸部 菭移栄死，1例は原発栄，頚部リンバ節上も制御で た遠陌枟移死だった。 5 年以上生存 1 例， 3 年考 経て生存中のもの3例である。

3) 第 3群: 舌可動部広簛群 (図 3-1) 症例数 4 例

(1) TN 分布

T3: 3例，T4：1例で，T3の3例中 2 例吕 $\mathrm{N}(+)$ で他は Noだった。

（2）切除籍围と易所再登（表 5)

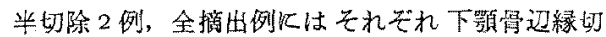

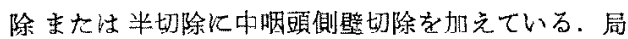

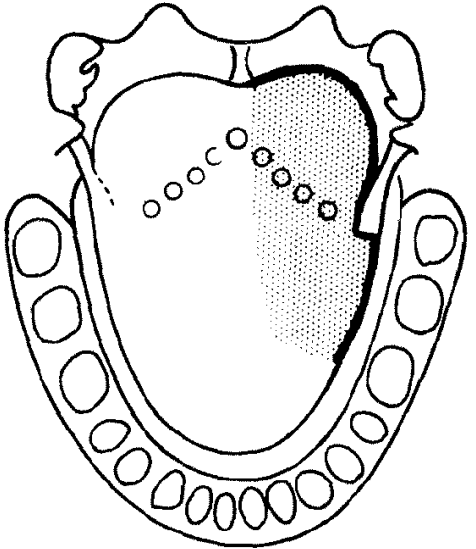

図 4-1 舌可動部・舌根群

表 6

\begin{tabular}{|c|c|c|c|c|}
\hline 舌 & 下颚鬲 & 他 & 例数 & 敂䓄再発 \\
\hline 部分切除 & 辺緣切除 & 中咽磌側壁 & 1 & $(-)$ \\
\hline 半切除 & & & 2 & $(-)$ \\
\hline$"$ & & 中咽頭倒壁 & 2 & $(-)$ \\
\hline 全摘出 & & 中咽頭側壁 & 1 & $(-)$ \\
\hline
\end{tabular}

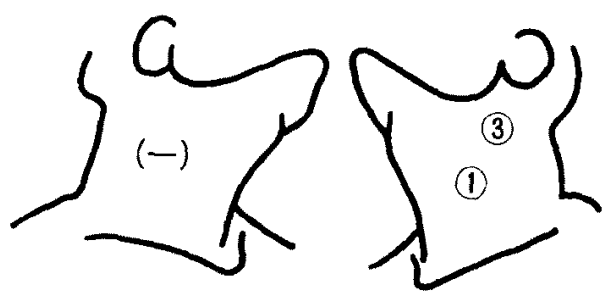

図 4-2 靧部転移 3 例

所再発は半切除例飞 1 例，全摘出例飞1例の部2例 にみられた。再発時期はいずれす術後4力月だった。

(3) 頸部リンパ簛転移 (困 3-2)

後発転移は舌半剠除後再発をきたした峢に認的ら れた。部位は同側の顎下部，上深頸部にみられた。

この群では舌中隔な越光た症例が2例あったがそ のうち頸部耺移の出現したのは1例のみでこの例 问側八の轱移だった。

局所雨発をきたした2例が原発学死，1例他病死， T3N1の1例のみ 5 年生存している. 
4) 第 4 群: 舌可動部.舌根進展群（図 4-1)

\section{定例数 6 洌}

(1) TN 分布

T2: 3例, T3：2例, T4: 1 例で, T2, T3 の各 1

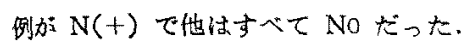

（2）切除範囲之局所再発（表 6)

部分切除 1 例, 半切除 4 例, 全摘出 1 例, 下顎骨 虭辺粶切除 1 例だった. 同側の中咽頭側壁の切除を 4例飞加えている。

(3) 新部りンバ節転移 (図 4-2)

顠部リンパ節転移は3例で，後発抎移はT4No の 1列にみられた。3例とも同側上深碩部に枟移を認 めた.

全例局所再発なく 5 年生存している。

5）第 5 群：舌可動部・口腔底進展群（四 5-1）

症例数 5 例

(1) TN 分布

T2：2例，T3：1例，T4：2例て，T2，T3の各1 例が Naで他は $\mathrm{N}(+)$ だった。

(2) 切除籍囲之局所再発（表 7)

半切除 2 例, 部分切除, 西全揞出，全摘出各 1 例 て，下顎骨の半切除を 1 例に，辺縁切除を 2 例に施 行した．局所再発は 3 例でいずれ毛切除底部，つ亲

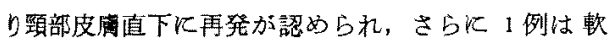
口䓝断端に再登丟認めたが，これは皮弁下に再発し

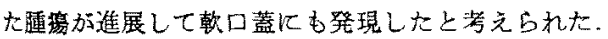

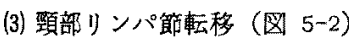

颈部リンパ節転移は 4 例に認められた。この群は 下深铰部，副神経部儿も転移の分布が認められた。

腫瘍死は 4 例で，ちち2例は原発单死だった。1 例住局所再発後の頚部りンパ節転移死，1例は局所 は制御されていたが後発の頸部りンパ転移出現後に 遠院転移死した．T3No の1例のみ2年生存してい \%。

6) 第 6群：舌可動部 - 舌根 - 口腔底准展群（図 6-1） 应例数 8 例

(1) TN 分析

T2: : 例, T3: 4例, T4: 3例て，T301例と T4

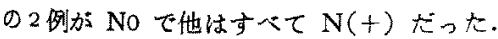

（2）如除籍囲之搨所再発（表 8)

半切除 6 例，严全摘出 1 例，全摘出 1 例て下顎骨 は辺縁切除，部分切除各 1 例を施行している，舌半 切除の 1 例は中咽頭側壁まで切除している。局所再

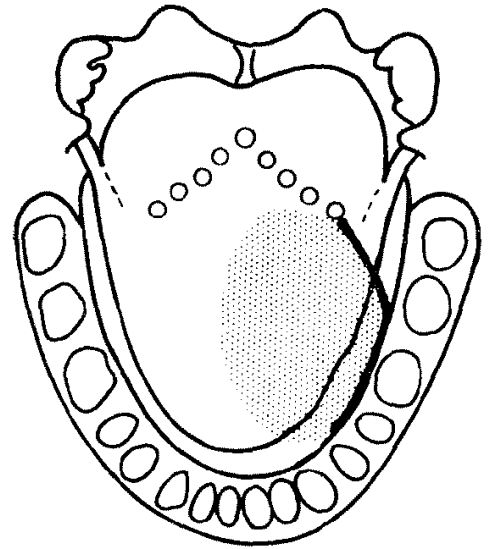

圆 5-1 舌可動部・日腔底群

表 7

\begin{tabular}{|c|c|c|c|}
\hline 舌 & 下顎骨 & 他 例数 & 局所再発 \\
\hline 部分切除 & 辺稼切除 & 1 & $(-)$ \\
\hline 半切除 & & 1 & 1-切除底部，歊口蓋断端 \\
\hline$"$ & 半切除 & 1 & $(-)$ \\
\hline 悪全摘出 & 辺緑切除 & 1 & 1-切除底部 \\
\hline 全摘出 & & 1 & 1-切除底部 \\
\hline
\end{tabular}

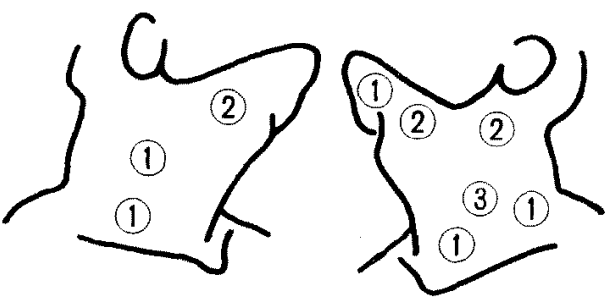

图 5-2 頙部枟移 4 例

発は 3 例で，2例は舌正中断端に，1例は切除底部 に再発老認めた舌正中断端再発例の2例は切除標本

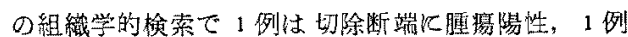
は断端 $5 \mathrm{~mm}$ のところまで腄揬が進展していた，再

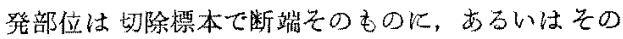

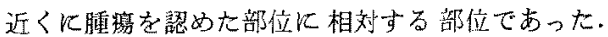
切除底部儿再発した1例は舌中䧣を越光ていたが， 特に切除底部淁しているということはなく，切除 標本の検討と再発部位の関連は見いだせなかった。 


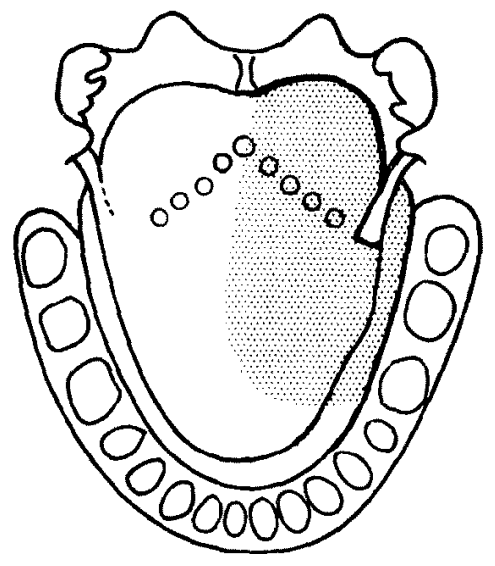

図 6-1 舌可動部・舌根・ 口靕底群

表 8

\begin{tabular}{|c|c|c|c|c|}
\hline 舌 & 下旗骨 & 他 & 例数 & 局所再発 \\
\hline 半切除 & & & 4 & 1-舌正中断端 \\
\hline$n$ & & 中咽頭側壁 & 1 & $(-)$ \\
\hline$"$ & 辺縁切除 & & 1 & 1-舌正中断端 \\
\hline 互全摌出 & 部分切除 & & 1 & $(-)$ \\
\hline 众摘出 & & & 1 & 1-切除底部 \\
\hline
\end{tabular}

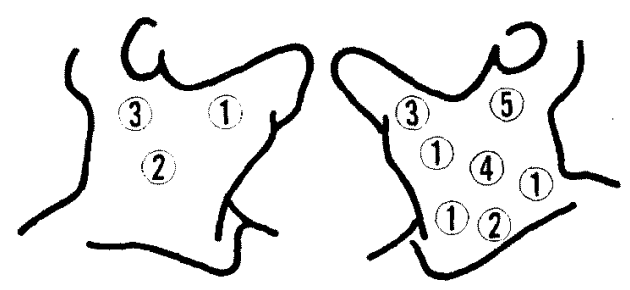

図 6-2 頻部祛移 8 例

(3) 頸部リンパ節枟移（四6-2）

No であった2例にす徭発の頸部りンパ節転移が 山現し, 結局 8 例全例飞転移を認的た. その占居部

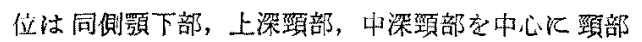
全体飞，対側では上梁頸部飞耺移が翟められた。 た2例飞後日上方の伤咽頊りンパ節八の転移を証め t.

腫㕠死は 7 例で，うち3例は原発栄死，4例は局 所，䫫部上屯に制御された遠隔転移死だった。 T2N2

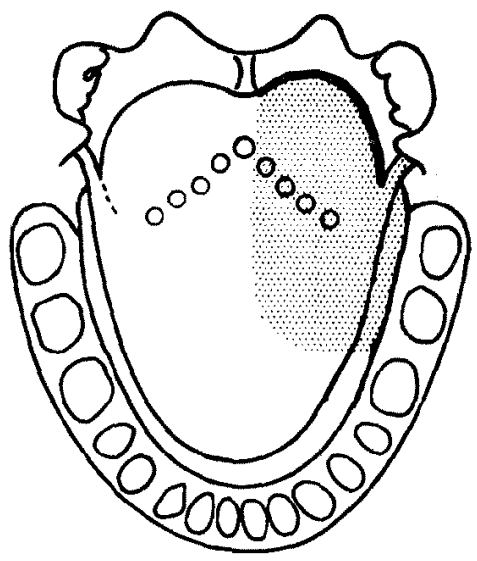

图 7-1 舌可動部・舌根・日腔底・前口蓋马群

表 9

\begin{tabular}{|c|c|c|c|c|}
\hline 舌 & 下顎骨 & 他 & 例数 & 局所再発 \\
\hline 西全摘娃 & & 中咽䕱側壁 & 1 & $\begin{array}{c}\text { 1-軟口蓋断端 } \\
\text { 切除宾部 }\end{array}$ \\
\hline 全摘出 & 辽緣切除 & 前口蓋弓のみ & 1 & 1-軟口蓋断端 \\
\hline$"$ & 半切除 & 中咽䣼側壁 & 3 & $(-)$ \\
\hline
\end{tabular}

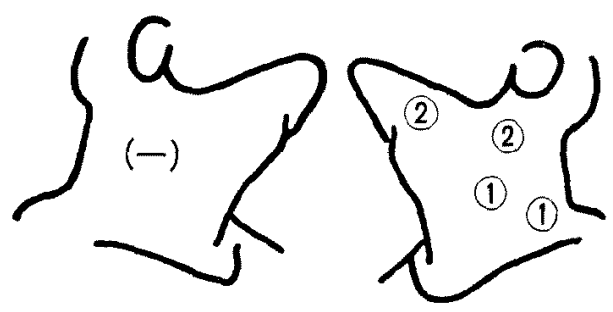

图 7-2 䫫部枟移 4 例

の1例のみ 4 年生存している。

7) 第 7 群：舌可勤部・舌根・只腔底・前口蓋弓准展群 (四 $7-1$ )

症例数 5 例

(1) $T N$ 尔布

T3: 1 例, T4: 4 例て, T4の 2 例が $N(+)$ で の他㹥 Noだった。

（2）切除筑䎴上局所再発（表 9)

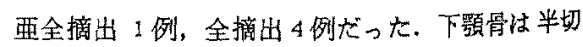
除または辺縁切除を全絪出例の全例火施行している. 
局所再発は 2 例で，いずれも十分な surgical margin をとっているともかかからず同側瑱口盖断端儿みら

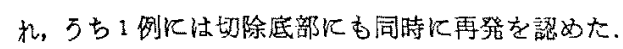
この例では軟口盐上切除庭部の再発部飞連続性がな く，别㑑の再発と考光られた。

(3) 頸部yンパ節枟移 (図 7-2)

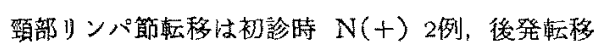
2例の計4例飞みられ，いずれ毛同側だった．部位 峙同倒顎下部，上深頸部を中心江分布していた。局 所再発老きたした 2 例が原発栄死，3例加他病死て 全例死亡している.

\section{考按}

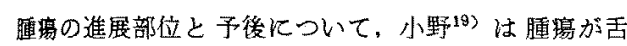
根，口腔底飞進展すると転移が增加し予後が悪い上述 ヘ，Tulenko $o^{15 y}$ も同様の意見を述べている.

また，舌瘦の予後は頙部への転移の有無とその処理に よるところが大きいことは疑いのないとこるであるが18 255293，局所の再発す残念ながら予後の悪化の一团となっ ているととも事実である。藤谷 ${ }^{21)}$ は琞射後再発舌癌 26 列化ついて原発，再発部位の検討を行い，1年以内の再 発住原発巣の関連が大きく腫場死につながることが多い としている.

Simonds ${ }^{23)}$ 怯局所制御のできない例はその $89 \%$ が 3 年以内に死亡すると述べ，Spiro ${ }^{283}$ も原発巣の再発が治 漛失敗の原因と埌告し，さらに多くの報告が局所制衙の 重要性を述へている。

外科療法の点からみると，Marchetta ${ }^{28)}$ が早期例でも 㕕籍囲飞切除することが最季効果的であるとしているの 飞対し，岩井 ${ }^{289}$ は進展例では手衔が必要であるが，舌

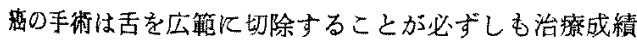
を上けるすのではないとしている。しかしそのいず机似 しろ，腫湶の確実な切除が必要であることにはかかりが 啝以。

過去, 舌癌治療後の局所再発の報告は数多いが，街前 治展の影響のない手街例での報告はほとんどみられな い. 险埸の正確な進展籍囲と再発や転移の部位との関連 を検討することは再発転移の多い舌癌を治療するにあた って有用でありひいては生存率の上昇卷寄与すると考元 ろ.

[躍床所見之病理組蟣学的所見について]

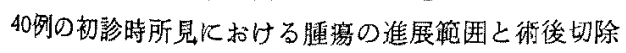
標本炕よる病理組織学的な進展範围之を比較してるる

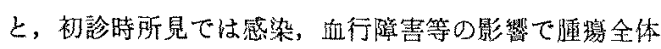

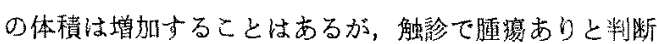
したとこる一特に正常組織との境界部て問題となる一

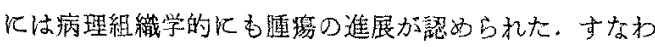

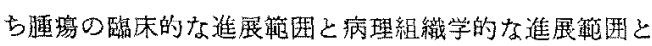
はほほ一致していた。

[原発栄の切除について]

分類した 7 群のうち局所再発のなかったのは第 $\mathrm{I}$ 群, 第 2 群，第 4 羷だった。

第 1 群, 第 2 群では部分切除，ま大は半切除て良い上 考えられる。

第 4 群の占根進展例では扁桃简炕再発する例が多いと されているが123，扁桃営切除例，非切除例のいずれる再 発はなかった。このことから舌根准展例での中咽頭側壁

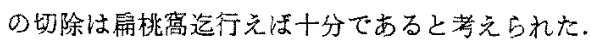

$\mathrm{Shah}^{\mathrm{30}>}$ 泣原発腫煌の深部進展例, 扣よび断端腫揚陽 性例は失敗例が多いと報告している。

40例のう方局所再発の諗められた症例は10例だった。 乙かし、1例で 2 力所，士なわち切除底部之軟口蓋断端

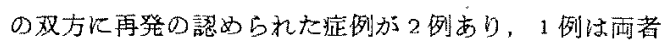
飞連繶性がなく別々の再発上判断したが，㫗う1例は明 らかな連繶性があるので主な再発は切除底部上考元、こ の部の再発のみとして报った。このため以下の检討は 11 例で行っ地。

局所再発までの期間は Gilbert ${ }^{313}$ は一次治瘵後 2 年以 内，服部芆は12力月以内が多いとしているが，竹田2 はさらK限定して6力月以内としている. 今回の症例保 和订る再発までの期間は最短 2 力月, 最長 8 力月, 平均 4.1力月だった.

11 例の弓ち断端腫陽陽性例は 2 例, 切除断端から腫埸 までの距維が切除標本で $5 \mathrm{~mm}$ 以下の症例が 3 例， 5 $\mathrm{mm}$ 以上 $1 \mathrm{~cm}$ 米满の例加 2 例, $1 \mathrm{~cm}$ 以上のものも 4 例 あった。

手術時 safety margin をどの程度とるかという問題で は絶党ず悩まされるが，切除断端と腫愘との距離が近い 程, 当然のことながらその部での再発の可能性が高いこ とを念頭任置くべきである。しかし解剖学的な制約と， 上り良い街㣪機能を保っことを考えると，2〜3cm の 余裕をつけることは必ずしも容易ではない，本研究の対 象例では切除断端上睡境との距䑾が正中側では $0.5 \mathrm{~cm}$ でも再発はないが，底部や軟口蓝では $1 \mathrm{~cm} の$ 余裕があ っても再発老見た。

再発部位でみると舌正中断端 2 例, 切除底部 7 例, 軟 


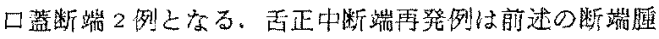
爆陽性洌だった。

切除底部再発例 Z例中, 術前随揊が口腔底に進展して いた例が 5 例で，他の2 例も口舡底に接していた.この 部の手術仕 pull through method を用いて垚り, 切除

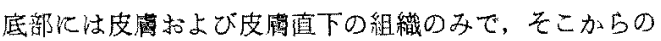
再発は考炕くい，また下顎骨縁で再発はなく，この ため残存舌测の古骨付近加らの再登加切除底部儿焦展し

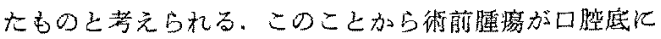
進鼠している例，あるいは接している例です頸部皮磨直 下での再発の可能性が高いため，このような症例での底

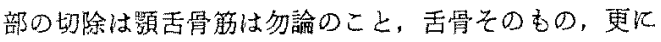
は喉頭仅及゙切除が必要てあると考えた。

軟口蓝断端再発例 2 例はいずれも術前に腄焬が前口蓋

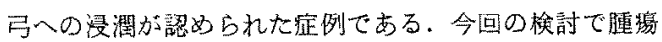
が舌根儿進展していた症例は19例方った。この19例は同

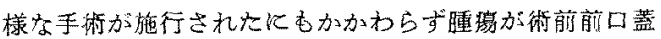

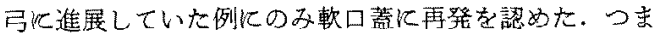

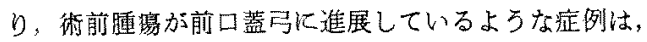

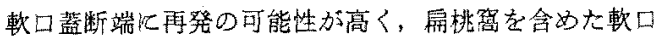
蓋での十分な safety margin 范つけての切除, 場合によ っては软口蓋半側の切除が必要と言える。

下顎骨の切除の有無での局所再発飞下顎骨切除例を含 をT2，T3，T4計 36例でみると，下颚骨切除群 12例 中 4 例，韭切除群 24 例中同しく6例と再吐率江差は られない。切除群，韭切除群とす下顎骨辺縁での再発は。

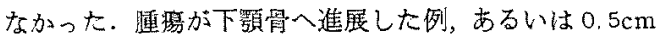
以内に近接した例では下顎骨の切除はどうしても必要と

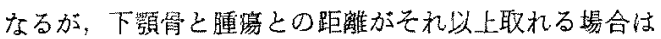

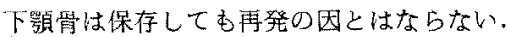

[巠部リンパ節転移について]

頸部リンパ節への枟移が尒後関係することは当然で ある、斉藤

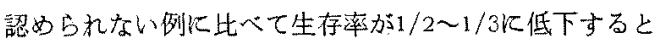
述へているが，Whitehurst ${ }^{33)}$ む同様の報告をして括り，

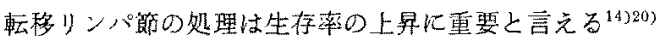
24)26)34).

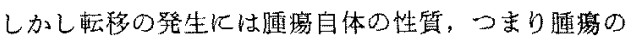
悪性度, 発育形式, 打よび宿主の感受性, 抵抗力等樽々

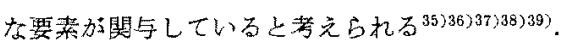

Whitehurst 仗さらに，腫掦が大きくなればその転移 率は上昇すると述でているが，今回の40例でも確か反そ

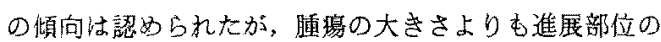

方がより枟移の発生汇閶与していると考えられた。

舌のリンバ流は過去多数の報告化よりほほ明らかにさ

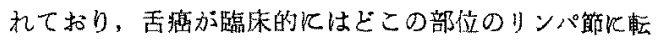
移を起こしやすいかの報告もみられ，奥田 ${ }^{12}$ は舌縁部

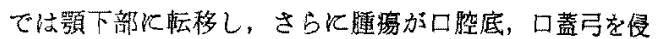
すと顎下部への転移率は增加する，背部では頃下嘼，対 側颚下部への転移が認められると報告している。

Martis $^{10)}$ は舌縁部は顎下部, jugulo-digastric, jugulocarotid nodes（いずれも上深頸りンパ節）へ，背部か jugulo-digastric（上深頸リンパ節）, jugulo-carotid, jugulo-omohyoid nodes (中㳭頸りンバ節) へ，時に傍 咽頭リンパ節人転移すると報告し，Droulias ${ }^{20)}$ も同栚 の報告をしている。

田代》は舌根進展例飞頚部リンパ節転移が多いとして いる.

頸部リンパ節転移は合㖕17例飞㒛めbれた。このうち 後発枟移は12例で，局所再発が認められず移のみ認め られたのは 7 例だった。この7例の転移出現までの期間 は最短 1 力月, 最長11力月, 平均 5.6 力月だった。

腫湯の占居部位により原発学を前述のごとく? 群《分

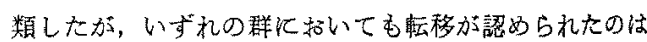
同側顎下部，拉よ゙、上深頸部だった。次いて juguloomohyoid nodes を中心とした中㳭頸部（７群中6群） に多かった，対側入の枟移は舌可動部前方怙上び後力限 局群，舌可動部・ 口腔底進展群，舌可動部・舌樶・ 口腔 底進展群の 4 群25例中 7 例にみられたが 5 例は淩発転移 だった。この5例のうち同側郭清後の症例が 4 例で，1

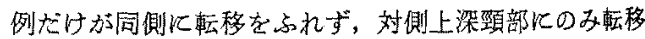
が出現した。

対側轻移のうち，上記 4 群の以ずれにす轻移が認めら れたのは顎下部だった，4群中原発巣進展が口㕵底化及

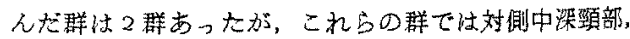
下深頸部化も枟移兴認めた。

今回の症例加ら中咽頭上壁た崔壁に進展した群 5 例を除いた35例の口腔底洼展の有無による頸部りンパ節 転移の發生率，执よび部位につき，舌可動部（前方・後 方・広箅）群招よび舌可動部・舌根群について比較梌討 した。

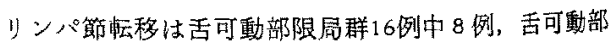

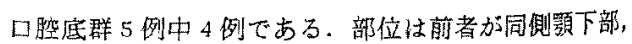
上深頸部を中心に転移があられるのに对し，後者蛙さら に下方，対側下方飞屯転移が出現している，(表10，因 $1-2,2-2,3-2,5-2)$ 
表 10 口舡底准展の有無による镍部転移の比較 (1)

\begin{tabular}{|c|c|c|}
\hline & 舌可動部程 & 舌可動部 - 口腔底群 \\
\hline 率 & 8 例/16例 & 4 例/ 5 例 \\
\hline 部位 & 同側買下部 - 上㳭頸部中心 & 压籍 \\
\hline
\end{tabular}

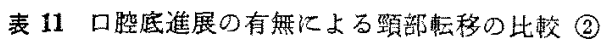

\begin{tabular}{|c|c|c|}
\hline & 舌可動部・舌根群 & 舌可動部·舌根・口整底群 \\
\hline 率 & 3 例/ 6 例 & 8 例 / 8 例 \\
\hline 部位 & 同側中深䫫部去で & 広 籍 \\
\hline
\end{tabular}

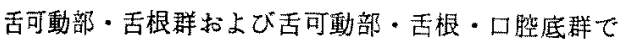
の転移活舌可動部・舌根群6 例中 3 例, 舌可動部・舌根

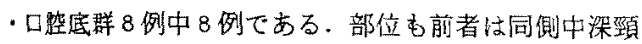

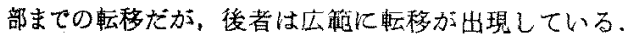
この車群をあわせて，口腔底への進展の有無での枟移発

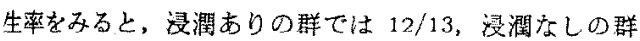

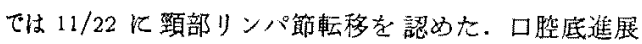
群のリンパ節転移発生頻度は浸潤なしの群より有意高 く腔底八進展したものでは頸部りンパ節轻移が必発で あるといってる過言ではない。

初診時 No症例儿対する頸部新清術は予防的にする か、転移出現時汇するかで意見の分かれるとこるである。 本研究のこれまでの例では，口腔底進展例等頸部リンパ

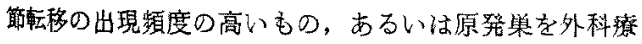
法で治療する場合は予防郭清術を，その他のものては原 発紧の治爒が Ra 針等であればリンパ節転栘が出現して 加ら垶清するという方針で良いと考えた。

$$
\text { ま ¿ }
$$

召和40年から56年の17年間に国立がんセンタ一西面頸科 で拁廉した舌病症例 531 例中外科療法を主体几行った扁

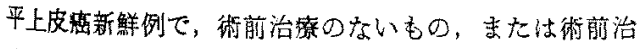
療炕よる影響を認めない40例を䠋鹊の占居部位によって

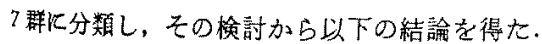

1. 䐈嫁の䠦床的な進展部位と病理組織学的な進展部位 は注ほ一致していた，術前の十分な触診は手術範囲の汱

定，予後推定仼重要である。

2. 原発策の切除汸て

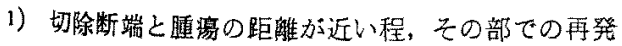
の可能性が高い。
2）術前腫揚が口整底に進眼している例，むるいは接 している例でも新部皮成直下での再発の可能性が高

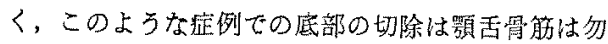
諭のこと，舌霄上組織の全切除が必要で，舌胃の切 除む考虑すべさでる。

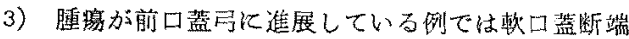
ての再発の可能性が高く、このような症例では郎桃

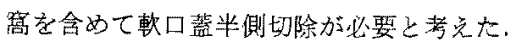

4）腫墔が下顎骨に進展している例は別として，下顎

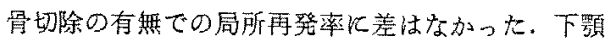

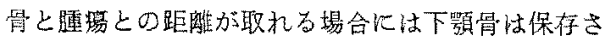
れ得ると考える。

3. 䫓部リソパ節服移について

1）嗹場の占居部位により分類した7群のいずれにも 転移が訪められた部位は，同㑡顎下部，上澡顎部だ った，次いで同側中㳭頸部に多吕った。

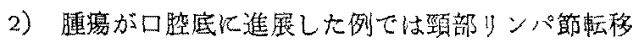

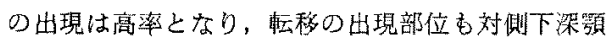
部まで広籍な領域に及んだ。

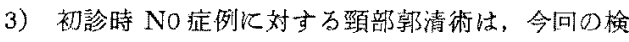
討からは口整底進展例等頸部りンバ節枟移の出現頻 度の高いもの，あるいは原発學を外科療法で治療す る場合には予防郭清術をその他のものでは原発巣の 治療がRa 針等であれば転移が出兒してから郭清す るといる方釗で良い。

\section{参支献}

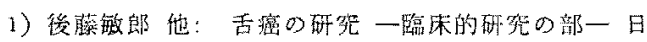
耳鰲 67：621-630，1965.

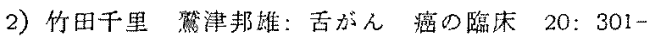
$310,1974$.

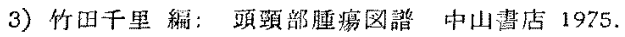

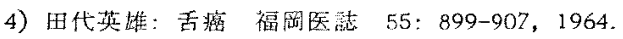

5) Fletcher $\mathrm{GH}$ and Stovall M: A study of the explicit distribution of radiation in interstitial implantations. II. correlation with clinical results in squamous cell carcinoma of the anterior twothirds of tongue and floor of mouth. Radiol 78 : 766-782, 1962.

6) Vermund $\mathrm{H}$ and Gllin FF: Role of radiotherapy in the treatment of cancer of the tongue. a retrospective analysis on TNM-staged tumors treated between 1958 and 1968 . 
7) Donaldson RC et al: Total glossectomy for cancer. Am J Surg 116: 585-590, 1968.

8）上野正：口腔癌心治療飞関寸研究口病誌 36 ; $4-19,1969$.

9) Beaver $B$ et al: Primary procedure in carcinoma of the tongue: local resection versus combined local resection and radical neck dissection. Current Surg 39: 405-407, 1982.

10) Martis CS: Cancer of the tongue: evaluation of surgical treatment of 123 cases. J Maxillofac Surg 8: 340-347, 1980.

11) Mendelson $B C$ et al: Neck dissection in the treatment of carcinoma of anterior two-thirds of the tongue. Surg Gynecol Obstet 143: 75-89, 1976.

12）奥田稌他：舌癌の轱移について 耳喉 36：907$914,1964$.

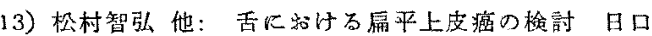
外誌 24：269-275，1978.

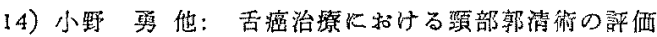
㾹の臨床 26: 123-130, 1980 .

15) Tulenko $J$ et al: Cancer of the tongue comments on surgical treatment. Am J Surg 112: $562-568,1968$.

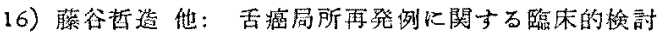
耳糇 48: 51-55，1976.

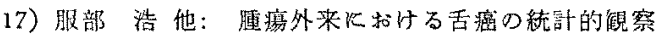
耳㑇 $41: 653-657,1969$.

18) James $A G$ : Evaluation of failure in treatment of oral cancer. Am J Roentgenol 83: 421-431, 1960.

19）小野雪：古がんの予後火影蔀走及ぼす因子の研究 日耳睤 80：146-154，1977。

20) Droulias $C$ and Whitehurst JO: The lymphatics of the tongue in relation to cancer. Am Surg 42: 670-674, 1976.

21）藤谷哲造他：枚射線治療後再発した舌癁の進屡模 式 革络 49:43-50，1977.

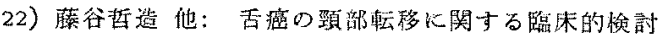
耳䢵臨床 70: 939-946, 1977.

23) Simonds JN et al: Result of radical treatment for intraoral cancer. Am J Surge 106: 819$825,1963$.

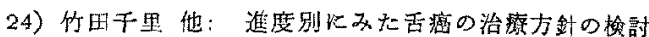
日癌治 2：261-269，1967.

25) Kinsey DL: Evaluation of failures in the treatment of lingual carcinoma. Arch Surg 84: 670$674,1962$.

26) Leipzig $B$ et al: Treatment of cervical lymph nodes in carcinoma of the tongue. Head and Neck Surg 5: 3-9, 1982.

27) Spiro $\mathrm{RH}$ et al: Evaluation of radical surgical treatment of advanced cancer of the mouth. Am J Surg 116: 571 -574, 1968.

28) Marchetta FC: Management of "localized" oral cancer. Am J Surg 134: 448-449, 1977.

29）岩井一他：舌癌の手術的治療以対する考察耳

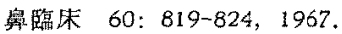

30) Shah JP et al: Carcinoma of the oral cavity: factors affecting treatment at the primary site and neck. Am J Surg 132: 504-507, 1976.

31) Gilbert EH et al: Cancer of the oral tongue and floor of the mouth: fifteen years experience with linear accelerater therapy. Cancer 35: 1517 $-1524,1975$.

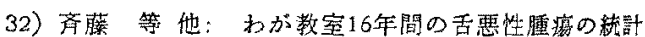
的観察 耳颃 54:29-36, 1983.

33) Whitehurst JD and Droulias JO: Surgical treatment of squamous cell carcinoma of the oral tongue. factors influencing survival. Arch Otol 103: 212-215, 1977.

34) Chu W et al: Result in supranyoid, modified radical neck and standard radical neck dissection for metastatic squamous cell carcinoma. recurrence and survival. Am J Surg 136: 512-515, 1978.

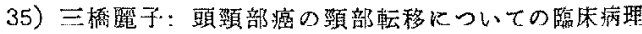
学的榆討 巨耳舉 71:621-638, 1968.

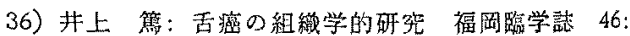
1039-1059, 1955.

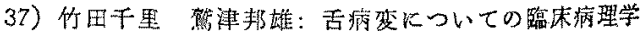
的考察 耳屡 12: 39-48, 1969 .

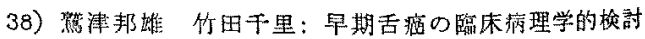
第二做 口科鼓 18：205，1969.

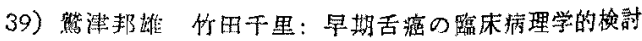
第三報 口科誌 19：394-395，1970. 
稿を終わるに臨み，御校閲を睗り，貫重な御助言，御 指導をいたたききした竹田于里教授に深謝致します。

本研究の計画から完成まて終始御指導, 御助力をいた

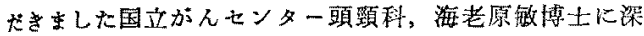
甚なる謝意を表しなす。

本研究の筫料を快く提供して下さり，また御指導下さ った国立がえセンタ一頭项科，小野尊博士，篮津邦雄博 土謝意を表します，更に，本研究に御協力いただいた

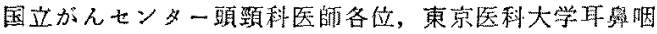

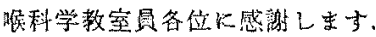

本諭交の要旨は，第21回日本癌治療学至総会（1983） に路いてロ演した。

（原嚆受付 昭和59，1，31日）

别剧請求先 T160東京都新宿区西新摍 6-7-1

東京医科大学耳舆咽喉科学教室大山和一郎 